\title{
H3N2 canine influenza virus and Enterococcus faecalis coinfection in dogs in China
}

\author{
Liwei Zhou ${ }^{1 \dagger}$, Haoran Sun ${ }^{2 \dagger}$, Shikai Song ${ }^{2}$, Jinhua Liu², Zhaofei Xia' ${ }^{1}$ Yipeng Sun ${ }^{2 *}$ and Yanli Lyu ${ }^{1 *}$
}

\begin{abstract}
Background: In May 2017, 17 dogs in a German Shepherd breeding kennel in northern China developed respiratory clinical signs. The owner treated the dogs with an intravenous injection of Shuang-Huang-lian, a traditional Chinese medicine, and azithromycin. The respiratory signs improved 3 days post-treatment, however, cysts were observed in the necks of eight dogs, and three of them died in the following 2 days.

Case presentation: Quantitative real-time PCR was used to detect canine influenza virus (CIV). All of the dogs in this kennel were positive and the remaining 14 dogs had seroconverted. Two of the dogs were taken to the China Agricultural University Veterinary Teaching Hospital for further examination. Two strains of influenza virus (A/canine/ Beijing/0512-133/2017 and A/canine/Beijing/0512-137/2017) isolated from the nasal swabs of these dogs were sequenced and identified as avian-origin H3N2 CIV. For the two dogs admitted to the hospital, hematology showed mild inflammation and radiograph results indicated pneumonia. Cyst fluid was plated for bacterial culture and bacterial $16 \mathrm{~s}$ rRNA gene PCR was performed, followed by Sanger sequencing. The results indicated an Enterococcus faecalis infection. Antimicrobial susceptibility tests were performed and dogs were treated with enrofloxacin. All 14 remaining dogs recovered within 16 days.
\end{abstract}

Conclusions: Coinfection of H3N2 CIV and Enterococcus faecalis was detected in dogs, which has not been reported previously. Our results highlight that CIV infection might promote the secondary infection of opportunistic bacteria and cause more severe and complicated clinical outcomes.

Keywords: Canine influenza virus, H3N2, Enterococcus faecalis, Coinfection

\section{Background}

Canine influenza virus (CIV) causes acute respiratory infection in dogs [1]. CIV of different origins and subtypes can infect dogs, however, two major subtypes, equine-origin H3N8 and avian-origin H3N2 CIVs, have established stable lineage in canine population. Avian H3N2 CIV was first identified in dogs in southern China in 2006 [2], and the following year, three H3N2 strains were isolated from dogs with severe respiratory disease in Korea [3]. Since then, H3N2 CIVs have been isolated from nasal swabs of dogs

\footnotetext{
*Correspondence: sypcau@163.com; luyanli_lab@163.com

${ }^{+}$Liwei Zhou and Haoran Sun contributed equally to this work.

${ }^{2}$ Key Laboratory of Animal Epidemiology of the Ministry of Agriculture and

State Key Laboratory of Agrobiotechnology, College of Veterinary Medicine,

China Agricultural University, No.2 Yuanmingyuan West Road, Beijing 100193 , China

${ }^{1}$ College of Veterinary Medicine, China Agricultural University, No.2

Yuanmingyuan West Road, Beijing 100193, China
}

experiencing respiratory clinical signs in several regions of China and South Korea [4-8]. In addition, H3N2 CIV has been transmitted to the United States, and was first isolated in the February-March 2015 outbreak in Chicago [9].

CIV infections are usually associated with upper respiratory tract clinical signs, including coughing and rhinorrhea. Severe disease, such as high fever, pneumonia or bronchopneumonia, and death have occasionally been reported [10]. Natural infections of CIV, especially in kenneled dogs, are likely to be associated with other respiratory pathogens, such as canine distemper virus (CDV), canine adenovirus type 2 (CAdV type 2), or canine parainfluenza virus (CPIV), which may increase the severity of disease [11].

Enterococcus faecalis is a Gram positive, non-sporeforming, facultative anaerobic bacterium, inhabiting the gastrointestinal tract of humans and animals, and also

(c) The Author(s). 2019 Open Access This article is distributed under the terms of the Creative Commons Attribution 4.0 International License (http://creativecommons.org/licenses/by/4.0/), which permits unrestricted use, distribution, and 
widely distributed in the environment [12, 13]. E. faecalis does not cause disease in healthy humans or animals, despite the nosocomial pathogenicity of Enterococci [14]. In dogs, there have only been a few reports of disease caused by $E$. faecalis, but the bacteria have been isolated from cases of urinary tract infections [15-17], periodontitis [18] and endocarditis [19].

CIV coinfection with respiratory bacterial pathogens may increase the pathogenicity [20]. Here, we report coinfection of CIV and E. faecalis in dogs for the first time. This case study emphasizes the importance of timely detection and effective treatment of CIV, to reduce the risk of secondary infections and improve outcomes.

\section{Case presentation}

In May 2017, all 17 dogs (aged 2-18 months old) in a German Shepherd breeding kennel in Beijing, developed coughing and rhinorrhea about 4 days after the introduction of a new dog. The breeder administered intravenous Shuang-Huang-lian $(60 \mathrm{mg} / \mathrm{kg} /$ day $)$ and azithromycin (10 $\mathrm{mg} / \mathrm{kg} /$ day). Shuang-Huang-Lian, a traditional Chinese medicine formulation comprising alcohol-water extracts of three herbs (Lonicerae Japonicae Flos, Scutellariae Radix, and Fructus Forsythiae), is widely used in China to treat respiratory infection as antimicrobial agents [21, 22]. Respiratory signs reduced 3 days post-treatment, however, cysts of various sizes (ranging from 5 to $10 \mathrm{~cm}$ in diameter), were observed by breeder in the ventral neck of eight dogs, and three of them died in the following 2 days. Two dogs with cysts and respiratory clinical signs (dog No.1 and No.2) were taken to the China Agricultural University Veterinary Teaching Hospital (CAUVTH) for examination.

Several diagnostic tests, including a general clinical examination, hematology and serum biochemistry, were performed for the two dogs (Table 1). Hematology showed mild increase in leukocyte, which indicated the animals had inflammation (Table 1). Thoracic radiographs revealed pneumonia (Fig. 1).

Nasopharyngeal secretions were collected from dog No.1 and No. 2 and four different commercial quantitative real-time PCR (qPCR) assays (Beijing Anheal Laboratory Co., Ltd., China) were used for CDV, CAdV type 2, CPIV and CIV detection. The samples were CIV-positive, but negative for CDV, CPIV and CAdV type 2.

Nasopharyngeal secretions from all 12 dogs remaining in the kennel were collected for virus detection as previously described, and all dogs were confirmed CIV-positive. Two samples from dog No.1 and No.2 were inoculated into the allantoic cavity of 9- to 11-day-old embryonated chicken eggs for virus propagation and isolation. Allantoic fluids were harvested after two blind passages and both presented haemagglutinating activity. Subsequently, viral nucleic acid was extracted and the HA and NA genes were amplified by RT-PCR, using universal primers for influenza A virus [23]. Phylogenetic analysis of $\mathrm{HA}$ and NA genes clearly demonstrated a close genetic relationship between the two isolates (A/canine/Beijing/ 0512-133/2017 and A/canine/Beijing/0512-137/2017) and were both avian-origin canine H3N2 (Fig. 2).

Serum samples were collected from 14 remaining dogs on the 4th day and 2 weeks post-onset of respiratory signs, respectively. Hemagglutination inhibition (HI) tests were undertaken using the A/canine/Beijing/0512$137 / 2017$ strain, and the samples collected 2 weeks post-onset were antibody-positive, while samples from day 4 were all negative, indicating seroconversion.

Dog No.1 was selected from 8 dogs with cysts for more investigation. Cyst fluid from dog No.1 was sampled using a fine needle aspiration. Cytological examination identified suppurative inflammation associated with numerous cocci (Fig. 3). Subsequently, $20 \mu \mathrm{L}$ of cyst

Table 1 Clinical data of dog No.1 and No.2 in this report

\begin{tabular}{|c|c|c|c|c|c|c|}
\hline \multirow{2}{*}{$\begin{array}{l}\text { Dog } \\
\text { ID }\end{array}$} & \multirow{2}{*}{$\begin{array}{l}\text { Species, age } \\
\text { (months), sex }\end{array}$} & \multirow[t]{2}{*}{ General examination } & \multicolumn{3}{|c|}{ Hamaetology } & \multirow{2}{*}{$\begin{array}{l}\text { Serum } \\
\text { chemistry }\end{array}$} \\
\hline & & & Index & Result & Reference interval & \\
\hline \multirow[t]{5}{*}{1} & \multirow{5}{*}{$\begin{array}{l}\text { German Shepherd } \\
\text { dog, 4, female }\end{array}$} & \multirow{5}{*}{$\begin{array}{l}38.9^{\circ} \mathrm{C} \text {, rough breathing sounds, } \\
\text { a cyst in the neck ( } 10 \mathrm{~cm} \text { in diameter) }\end{array}$} & $\mathrm{HCT}$ & $35.5 \%$ & $37.3-61.7$ & \multirow[t]{5}{*}{ Normal } \\
\hline & & & MCV & $57.3 \mathrm{fL}$ & $61.6-73.5$ & \\
\hline & & & WBC & $17.01 \times 10^{\wedge} 9 / \mathrm{L}$ & $5.05-16.76$ & \\
\hline & & & LYM & $5.18 \times 10 \wedge 9 / L$ & $1.05-5.10$ & \\
\hline & & & MONO & $6.96 \times 10 \wedge 9 / L$ & $0.16-1.12$ & \\
\hline \multirow[t]{5}{*}{2} & \multirow{5}{*}{$\begin{array}{l}\text { German Shepherd } \\
\text { dog, 4, male }\end{array}$} & \multirow{5}{*}{$\begin{array}{l}38.8^{\circ} \mathrm{C} \text {, rough breathing sounds, } \\
\text { a cyst in the neck ( } 5 \mathrm{~cm} \text { in diameter) }\end{array}$} & $\mathrm{RBC}$ & $5.53 \times 10 \wedge 12 / L$ & $5.65-8.87$ & \multirow[t]{5}{*}{ Normal } \\
\hline & & & $\mathrm{HCT}$ & $33.7 \%$ & $37.3-61.7$ & \\
\hline & & & MCV & $60.9 \mathrm{fL}$ & $61.6-73.5$ & \\
\hline & & & WBC & $16.93 \times 10^{\wedge} 9 / \mathrm{L}$ & $5.05-16.76$ & \\
\hline & & & MONO & $1.49 \times 10^{\wedge} 9 / \mathrm{L}$ & $0.16-1.12$ & \\
\hline
\end{tabular}




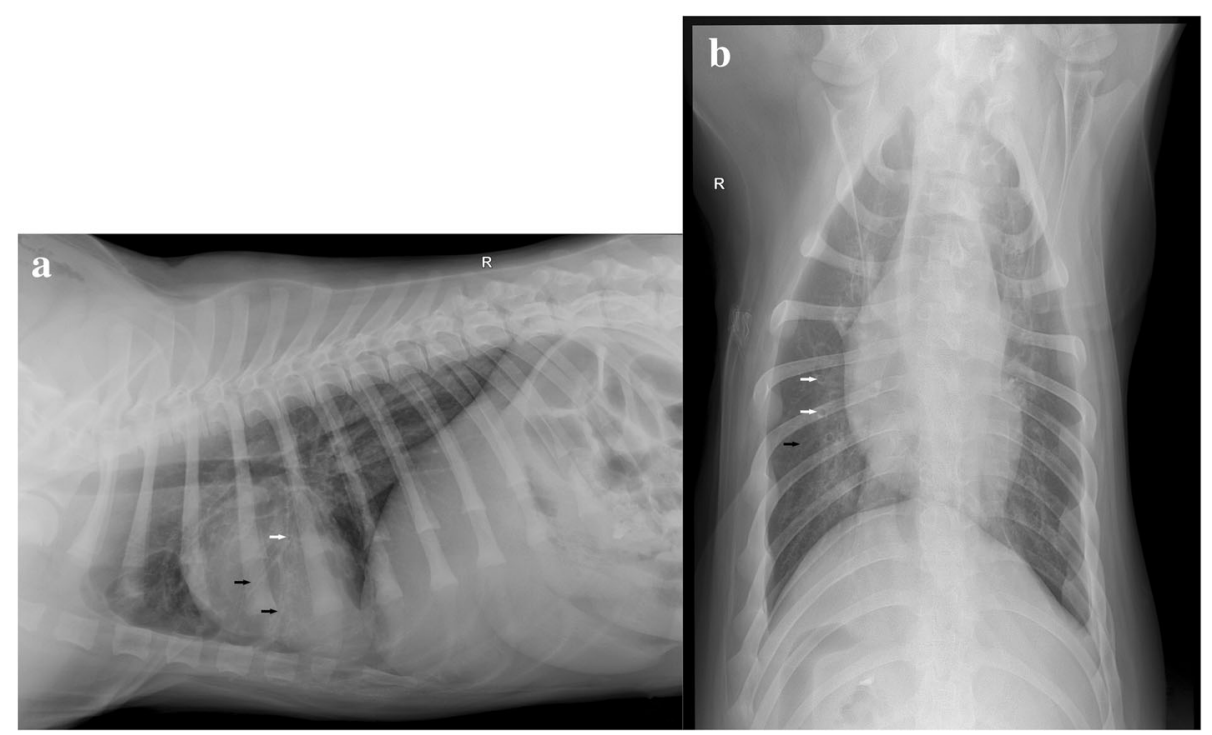

Fig. 1 Lateral (a) and ventrodorsal (b) radiographs of the thorax of dog No. 1. There is a typical bronchial pattern evidenced by tram lines (black arrow) and ring shadows (white arrow), as well as a mild increase in interstitial opacity (unstructured interstitial pattern)

fluid was plated on sheep blood agar plates for bacterial culture. After incubation at $37^{\circ} \mathrm{C}$ for $24 \mathrm{~h}$, non-hemolytic small colonies $(0.5-1 \mathrm{~mm}$ in diameter), appeared on the plates. To identify the species, bacteria from a single colony was cultured and whole genome DNA was extracted for PCR amplification of the $16 \mathrm{~s}$ rRNA gene [24]. Sequencing of the $16 \mathrm{~s}$ rRNA gene identified $E$. faecalis. Furthermore, antimicrobial susceptibility tests were carried out to provide guidance for clinical medication, and the results showed multidrug resistance, with sensitivity to enrofloxacin and norfloxacin (Table 2).

Treatment with subcutaneous $5 \%$ enrofloxacin $(10 \mathrm{mg} /$ $\mathrm{kg} /$ day), was administered for 5 days. Eight dogs without cysts recovered 1 week post-onset of respiratory signs, and a reduction in cyst size was observed in the remaining five dogs. All dogs recovered within 11 to 16 days of treatment.

\section{Discussion and conclusion}

Influenza A virus infection can cause respiratory symptoms in humans and many animals. Secondary bacterial infections, which are a common complication of influenza virus infection, may significantly increase the severity of the disease and result in poorer outcomes. In humans, Streptococcus pneumoniae, Staphylococcus aureus and Haemophilus influenzae are the three most frequently reported bacteria secondary to influenza infection. Other less common bacteria include Nocardia [25], Mycoplasma pneumoniae [26], Mycobacterium tuberculosis [27], Legionella pneumophila [28], and Campylobacter jejuni [29]. Choi et al. performed a retrospective analysis of 636 swine influenza virus (SIV) cases in pigs and found that Pasteurella multocida and Mycoplasma hyopneumoniae were the most common bacteria associated with SIV [30]. In addition, artificial infection tests demonstrated that coinfection of SIV with Haemophilus parasuis or Bordetella bronchiseptica aggravated lung injury in pigs [31]. In birds infected with influenza virus, Mycoplasma gallisepticum, Escherichia coli, Riemerella anatipestifer, Pasteurella multocida and other common bacteria have been detected [32, 33]. In dogs, however, apart from one study that isolated Staphylococcus pseudointermedius and Mycoplasma from the lungs of H3N2 CIV-infected dogs [34], few other bacterial coinfections have been reported.

In this case report, we describe a CIV outbreak in a breeding kennel in northern China. This is the first time that CIV coinfection with E. faecalis in dogs has been reported worldwide. In our case, all 17 dogs in the kennel were infected by CIV after the introduction of a new dog. Though the new dog showed no observable clinical signs when it was introduced into the kennel, it was among the first few dogs that showed respiratory symptoms. Previous study showed that clinically healthy dogs can carry respiratory pathogens and could act as sources of infection for susceptible dogs [35]. Therefore, the new dog might be the source of CIV infection. Additionally, 8 of the infected dogs developed cysts. We observed numerous cocci with similar morphology from cyst fluid using cytological examination, and cyst fluid was cultured and $16 \mathrm{~s}$ rRNA sequencing was performed. Then, E. faecalis was successfully identified, therefore, the dogs were treated with enrofloxacin and cyst sizes reduced. $16 \mathrm{~s}$ rRNA sequencing is a cost-effective and efficient 


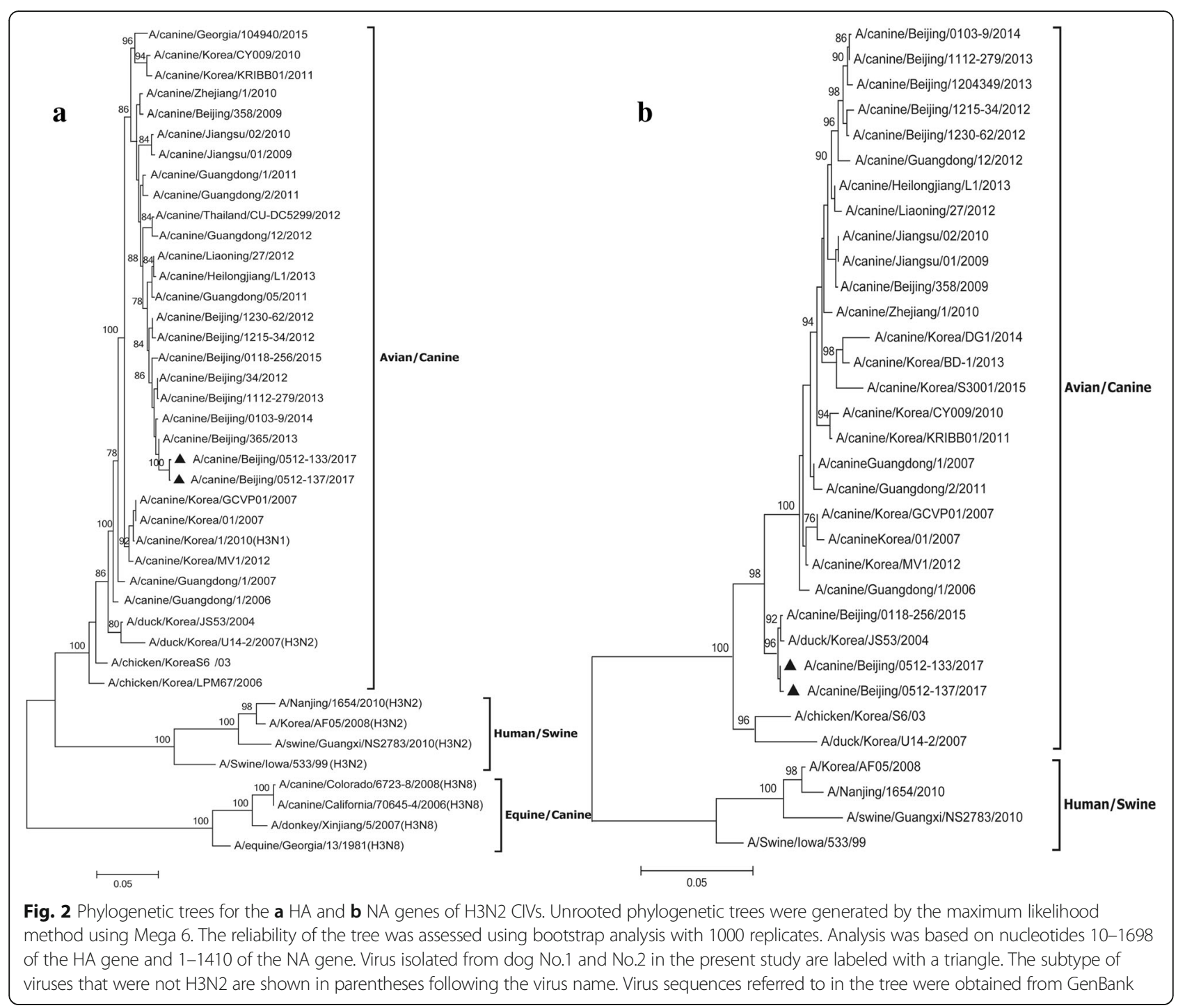

method to identify the species of bacteria, however, direct detection of the cyst fluid using metagenomics could be more accurate and comprehensive in identifying the pathogen that co-infected the dogs with CIV. In general, CIV infections are self-limiting, with high morbidity and low mortality. Animal experiments showed that the mortality rate of H3N2 CIV infection is low [3, 7]. In our case report however, three dogs died from coinfection of CIV and E. faecalis, therefore we hypothesize that $E$. faecalis infection increased the severity of the disease.

The increased risk of secondary bacterial infections in patients with influenza virus infection may be associated with a variety of factors. For example, an inflammatory response to viral infection may up-regulate expression of molecules that bacteria utilize as receptors, like platelet activating factor receptor can be served as attachment molecule for S. pneumoniae, one of the pathogens complicating influenza infection [36]. In addition, virus infection causes sustained desensitization to bacterial toll-like receptor ligands, affecting the normal bacterial clearance mechanism [37]. In our case report, the E. faecalis was similar to the Staphylococcus pseudointermedius [20] cited in other research as common commensal bacteria in dogs, which could cause opportunistic infections. There is no evidence that CIV infection increases the risk of E. faecalis infection in dogs, however, one study found that mice experimentally infected with H3N2 CIV, followed by Staphylococcus pseudointermedius $72 \mathrm{~h}$ later, resulted in increased bacterial colonization [20]. Meanwhile, studies have shown that immunosuppression enhanced E. faecalis colonization [38]. According to the breeder of the dogs in our case report, this was not the first time that he administered the same medical management for dogs experiencing respiratory clinical signs, however, no similar infection had occurred previously. We speculate that CIV infection affects the normal immune 


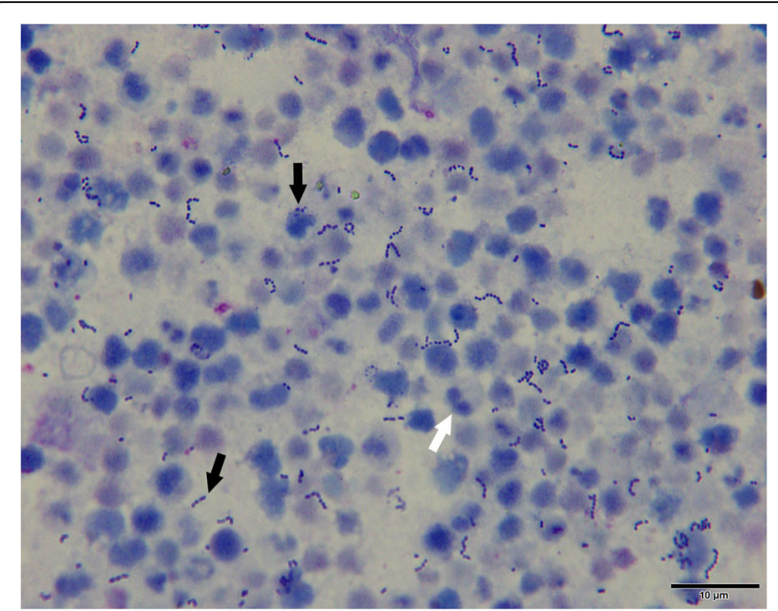

Fig. 3 Cytological examination of the cyst fluid from dog No.1. Large numbers of degenerative neutrophils (short arrow), with numerous intracellular and extracellular cocci (long arrow). Wright \& Giemsa

mechanism in dogs, making it more susceptible to opportunistic infections, such as E. faecalis. Therefore, in addition to symptomatic treatment, we recommend the use of broad-spectrum antibiotics in dogs with CIV infection, to control other possible infections.

Currently, CIV vaccines are rarely used in China, which has caused difficulties in preventing and controlling the epidemic of canine influenza. We emphasize that once dogs develop signs of upper respiratory disease, they should be tested for the presence of CIV infection and be quarantined from other susceptible dogs. In the meantime, since coinfection of CIV with bacteria may affect pathogenicity and disease progression, it is of great importance to recognize secondary bacterial

Table 2 Antimicrobial susceptibility test of clinical E. faecalis isolate from dog No.1

\begin{tabular}{ll}
\hline Antimicrobial agents & Result \\
\hline Penicillin & Resistant \\
Ampicillin & Resistant \\
Cefalexin & Resistant \\
Ceftriaxone & Resistant \\
Vancomycin & Resistant \\
Erythromycin & Resistant \\
Tetracyclines & Resistant \\
Chloramphenicol & Resistant \\
Florfenicol & Intermediate \\
Enrofloxacin & Sensitive \\
Norfloxacin & Sensitive \\
Clindamycin & Resistant \\
Amikacin & Intermediate \\
Doxycycline & Resistant \\
\hline
\end{tabular}

infection as a major clinical complication of influenza infection during disease assessment.

We described a CIV outbreak in a breeding kennel and have confirmed H3N2 CIV and E. faecalis co-infection. $\mathrm{CIV}$ and $E$. faecalis co-infected dogs had more severe consequences and longer duration compared with those with CIV infection, suggesting CIV infection might promote the secondary infection of opportunistic bacteria and cause more severe and complicated clinical outcomes. This emphasizes the importance of preventing bacterial exposure and improving health care during CIV infection.

\section{Abbreviations}

CAdV: Canine adenovirus; CAUVTH: China Agricultural University Veterinary Teaching Hospital; CDV: Canine distemper virus; CIV: Canine influenza virus; CPIV: Canine parainfluenza virus; PCR: Polymerase chain reactions; qPCR: quantitative real-time PCR; SIV: Swine influenza virus

\section{Acknowledgements}

We thank Yanyun Chen, Rongquan Dai, Qiong Zhang and Haixia Zhang for their advice in the case analysis. The authors thank the kennel owner for allowing us to publish this case report.

\section{Funding}

This work was supported by Beijing Science and Technology Program (Z171100001517008), the National Natural Science Foundation of China (31672573), Beijing New-star Plan of Science and Technology

(Z161100004916115), and by grants from the Chang Jiang Scholars Program.

Availability of data and materials

All the data and materials used in this report are included in the manuscript.

\section{Authors' contributions}

YS and YL were responsible for the study design. LZ and HS wrote the report. SS and LZ analyzed and interpreted the data. $J L$ and $Z X$ revised the manuscript. All authors read, commented and approved the final article.

\section{Ethics approval and consent to participate}

Not applicable.

\section{Consent for publication}

Written informed consent was obtained from the kennel owner for the publication of this case report and accompanying images.

\section{Competing interests}

The authors declare that they have no competing interests.

\section{Publisher's Note}

Springer Nature remains neutral with regard to jurisdictional claims in published maps and institutional affiliations.

Received: 30 September 2018 Accepted: 1 March 2019

Published online: 11 April 2019

\section{References}

1. Lee YN, Lee HJ, Lee DH, Kim JH, Park HM, Nahm SS, Lee JB, Park SY, Choi IS, Song CS. Severe canine influenza in dogs correlates with hyperchemokinemia and high viral load. Virology. 2011;417(1):57.

2. Li S, Shi Z, Jiao P, Zhang G, Zhong Z, Tian W, Long LP, Cai Z, Zhu X, Liao M. Avian-origin $\mathrm{H} 3 \mathrm{~N} 2$ canine influenza a viruses in southern China. Infect Genet Evol. 2010;10(8):1286-8.

3. Song D, Kang B, Lee C, Jung K, Ha G, Kang D, Park S, Park B, Oh J. Transmission of avian influenza virus (H3N2) to dogs. Emerg Infect Dis. 2008; 14(5):741-6.

4. Sun Y, Sun S, Ma J, Tan Y, Du L, Shen Y, Mu Q, Pu J, Lin D, Liu J. Identification and characterization of avian-origin H3N2 canine influenza viruses in northern China during 2009-2010. Virology. 2013;435(2):301-7. 
5. Lin Y, Zhao YB, Zeng XJ, Lu CP, Liu YJ. Complete genome sequence of an $\mathrm{H} 3 \mathrm{~N} 2$ canine influenza virus from dogs in Jiangsu, China. J Virol. 2012;86(20):11402.

6. Aznarte-Mellado C, Sola-Campoy PJ, Robles F, Rejón CR, Herrán RDL Navajas-Pérez R. Identification and genetic characterization of avian-origin H3N2 canine influenza viruses isolated from the Liaoning province of China in 2012. Virus Genes. 2014;49(2):342-7.

7. Teng Q, Zhang X, Xu D, Zhou J, Dai X, Chen Z, Li Z. Characterization of an H3N2 canine influenza virus isolated from Tibetan mastiffs in China. Vet Microbiol. 2013;162(2-4):345-52.

8. Lee E, Kim EJ, Kim BH, Song JY, Cho IS, Shin YK. Molecular analyses of H3N2 canine influenza viruses isolated from Korea during 2013-2014. Virus Genes. 2016;52(2):204-17.

9. leh V, Glaser AL, Toohey-Kurth K, Newbury S, Dalziel BD, Dubovi EJ, Poulsen K, Leutenegger C, Kje W, Brisbane-Cohen L. Spread of canine influenza A(H3N2) virus, United States. Emerg Infect Dis. 2017;23(12):1950-7.

10. Dubovi EJ. Canine influenza. Vet Clin North Am Small An Pract. 2008;38(4): 827-35.

11. B FR: Infectious diseases of the dog and cat, 4Th: Elsevier; 2012.

12. Prieto AMG, Schaik WV, Rogers MRC, Coque TM, Baquero F, Corander J, Willems RJL. Global emergence and dissemination of enterococci as nosocomial pathogens: attack of the clones? Front Microbiol. 2016;7:e193.

13. Fisher K, Phillips C. The ecology, epidemiology and virulence of Enterococcus. Microbiology. 2009;155(6):1749-57.

14. Arias CA, Murray BE. The rise of the Enterococcus: beyond vancomycin resistance. Nat Rev Microbiol. 2012;10(4):266

15. Kukanich KS, Lubbers BV. Review of enterococci isolated from canine and feline urine specimens from 2006 to 2011. J Am Anim Hosp Assoc. 2015; 51(3):148-54.

16. Wong C, Epstein SE, Westropp JL. Antimicrobial susceptibility patterns in urinary tract infections in dogs (2010- 2013). J Vet Intern Med. 2015; 29(4):1045.

17. Marques C, Belas A, Franco A, Aboim C, Gama LT, Pomba C. Increase in antimicrobial resistance and emergence of major international high-risk clonal lineages in dogs and cats with urinary tract infection: 16 year retrospective study. J Antimicrob Chemother. 2017.

18. Semedolemsaddek T, Tavares M, Braz BS, Tavares L, Oliveira M. Enterococcal infective endocarditis following periodontal disease in dogs. PLoS One. 2016;11(1):e146860.

19. Tessier-Vetzel D, Carlos C, Dandrieux J, Boulouis HJ, Pouchelon JL, Chetboul V. Spontaneous vegetative endocarditis due to Enterococcus faecalis in a rottweiler puppy. Schweiz Arch Tierheilkd. 2003;145(9):432.

20. Kalhoro DH, Gao S, Xie X, Liang S, Luo S, Zhao Y, Liu Y. Canine influenza virus coinfection with Staphylococcus pseudintermedius enhances bacterial colonization, virus load and clinical presentation in mice. BMC Vet Res. 2016; 12(1):1-11.

21. Committee. SP. Chinese Pharmacopoeia: Chemical Industry Press; 2010.

22. Gao Y, Fang L, Cai R, Zong C, Chen X, Lu J, Qi Y. Shuang-Huang-Lian exerts anti-inflammatory and anti-oxidative activities in lipopolysaccharidestimulated murine alveolar macrophages. Phytomedicine. 2014;21(4):461-9.

23. Hoffmann E, Stech J, Guan Y, Webster RG, Perez DR. Universal primer set for the full-length amplification of all influenza a viruses. Arch Virol. 2001; 146(12):2275-89.

24. Lindsay B, Pop M, Antonio M, Walker AW, Mai V, Ahmed D, Oundo J, Tamboura B, Panchalingam S, Levine MM. Survey of culture, GoldenGate assay, universal biosensor assay, and 16S rRNA gene sequencing as alternative methods of bacterial pathogen detection. J Clin Microbiol. 2013; 51(10):3263-9.

25. Kalenahalli KJ, Kumar NA, Chowdary KV, Sumana MS. Fatal swine influenza a H1N1 and mycoplasma pneumoniae coinfection in a child. Tuberk Toraks. 2016;64(3):246-9.

26. Tan CK, Kao CL, Shih JY, Lee LN, Hung CC, Lai CC, Huang YT, Hsueh PR. Coinfection with mycobacterium tuberculosis and pandemic H1N1 influenza a virus in a patient with lung cancer. J Microbiol Immunol Infect. 2011:44(4):316-8.

27. Sawai T, Yoshioka S, Matsuo N, Suyama N, Kohno S. A case of communityacquired pneumonia due to influenza a virus and Nocardia farcinica coinfection. J Infect Chemother. 2014;20(8):506-8.

28. Rizzo C, Caporali MG, Rota MC. Pandemic influenza and pneumonia due to legionella pneumophila: a frequently underestimated coinfection. Clin Infect Dis. 2010;51(1):115.
29. Kahar-Bador M, Nathan AM, Soo MH, Mohd NS, Abubakar S, Lum LC, Syed HS, Sam IC. Fatal influenza A (H3N2) and campylobacter jejuni coinfection. Singap Med J. 2009;50(3):112-3.

30. Choi YK, Goyal SM, Han SJ. Retrospective analysis of etiologic agents associated with respiratory diseases in pigs. Can Vet J. 2003;44(44):735-7.

31. Pomorskamól M, Dors A, Kwit K, Czyżewskadors E, Pejsak Z. Coinfection modulates inflammatory responses, clinical outcome and pathogen load of H1N1 swine influenza virus and Haemophilus parasuis infections in pigs. BMC Vet Res. 2017;13(1):376.

32. Sid H, Benachour K, Rautenschlein S. Co-infection with multiple respiratory pathogens contributes to increased mortality rates in Algerian poultry flocks. Avian Dis. 2015:59(3):440-6.

33. Capua I, Marangon S. The avian influenza epidemic in Italy, 1999-2000: a review. Avian Pathol J Wvpa. 2000;29(4):289-94.

34. Watson CE, Bell C, Toohey-Kurth K. H3N2 canine influenza virus infection in a dog. Vet Pathol. 2017;54(3):527.

35. Schulz BS, Kurz S, Weber K, Balzer HJ, Hartmann K. Detection of respiratory viruses and Bordetella bronchiseptica in dogs with acute respiratory tract infections. Vet J. 2014;201(3):365-9.

36. Peltola VT, Mccullers JA. Respiratory viruses predisposing to bacterial infections: role of neuraminidase. Pediatr Infect Dis J. 2004;23(1 Suppl):S87-97.

37. Didierlaurent A, Goulding J, Patel S, Snelgrove R, Low L, Bebien M, Lawrence T, Rijt LSV, Lambrecht BN, Sirard JC. Sustained desensitization to bacterial toll-like receptor ligands after resolutionof respiratory influenza infection. J Exp Med. 2008;205(2):323-9.

38. Guiton PS, Hannan TJ, Ford B, Caparon MG, Hultgren SJ. Enterococcus faecalis overcomes foreign body-mediated inflammation to establish urinary tract infections. Infect Immun. 2013;81(1):329-39.
Ready to submit your research? Choose BMC and benefit from:

- fast, convenient online submission

- thorough peer review by experienced researchers in your field

- rapid publication on acceptance

- support for research data, including large and complex data types

- gold Open Access which fosters wider collaboration and increased citations

- maximum visibility for your research: over $100 \mathrm{M}$ website views per year

At BMC, research is always in progress.

Learn more biomedcentral.com/submissions 